\title{
SAMSUN MEVLEVIHANESI
}

\author{
OSMAN KÖSE
}

\section{Giriş}

Mevlevilik, 13. asırda Konya'da hayat süren Mevlâna Celâleddin Rumi'nin görüşleri ve tasavvufi düşünceleri üzerine, onun ölümünden sonra gelişen bir tarikattır. 15. asrın yarılarından itibaren Osmanlı devletinde de gelişmeye başlamış ve hızla imparatorluğun her yöresine yayllmıştır. Bu çalışmada diğer vilayet ve sancak merkezlerinde olduğu gibi 16. asrın ikinci yarısında Samsun'da da kurulan mevlevihânenin, Osmanlı devletinin son dönemlerindeki durumu incelenecektir. Makale, bu zamana kadar Samsun Mevlevîhânesini konu alan iki çalı̧maya ek yeni bilgiler getirmenin yanında, Osmanl arşivine dayah olarak yapulan ilk araştırma olma özelliğine sahiptir ${ }^{1}$.

Bu çalışmada Samsun Mevlevihanesi bütün yönleriyle incelenmeyecektir. Her şeyden önce bu tür bir çalışma yapmak için 19. asrın ilk yarılarına kadar Samsun Mevlevihanesi ile ilgili yeterli bilgi ve belgelere ulaşılabilmiş değildir. Fakat bu çalışma ile Samsun Mevlevihanesi ile ilgili bilinenlere bazı katkıların sağlanacağı gibi, hatalı olarak bilinenlere de kaynaklar temelinde düzeltmeler önerilecektir. Gelecek zamanlarda arşivlere dayalı olarak Samsun Mevlevihânesi'ni konu alan akademik bir çalışma için de yol gösterici olabilir. Mevcut makalenin, başka araştırıcıları teşvik edici ve Samsun'daki yerel yöneticilerin tarihsel gelenek ve geçmişe sahip mevlevihâneyi tekrar bir kültürel mekân olarak ihya etmelerinde yol gösterici olması umulmaktadır.

\section{A- Osmanlı Devletinde Mevlevilik ve Mevlevihaneler}

Mevlevilik 13. asırda Konya merkezli olmak üzere Anadolu'da doğmuş ve daha sonraki asırlarda buradan çevreye ve dünyaya yayılmışır.

- Doş. Dr., Ondokuz Mayıs Üniversitesi, Eğitim Fakültesi, Samsun/TÜRKİYE, osmank@omu.edu.tr

'Samsun Mevlevihanesi ile ilgili söz konusu iki makale Konya Mevlana Müzesi Arşivi'ne dayanarak Nejat Göyünç ve derleme bir çalışma olarak Yakup Şafak tarafindan yapılmıştur. Nejat Göyünç, "Das Mevlevihane in Samsun", The foumal Ottoman Studies, XIV, (İstanbul 1994), s. 77 - 90, Yakup Şafak, "XIX.- XX. Yüzyllarda Samsun Mevlevihanesi”, Gę̧mişten Geleceğe Samsun II, Edit: Cevdet Ylmaz. Samsun 2008. s. 463 - 471. 
Bir tasavvufi yaşam ve düşünce biçimi olarak Mevlevilik, adını Mevlâna Celâleddin Rûmînin adından almışsa da onun zamanında sistematik bir yaşam biçimi veya düzeni hüviyetini kazanamamışır. Mevleviliğin bir sistemler manzumesi olarak ortaya çıkışı, Mevlâna Celâleddin Rûmînnin ölümünden sonra onun görüşleri ve düşünceleri etrafinda şekillenerek ancak oğlu Sultan Veled'in gayretleriyle olacaktır.

Mevlâna Celâleddin Rumi'nin babası Muhammed Veled, 1219 yılında Belh'ten göç ederek Konya'ya geldi. Onun, ailesiyle memleketini terk ediş sebebi, Moğol istilasının yarattığı kargaşa ve huzursuzluk ortamından uzaklaşma olarak bilinirse de, önemli bir etken olarak Harzemşah hükümdarı Muhammed Harzemşah'a kırgınlığının rol oynadığı sanılmaktadır ${ }^{2}$. Moğol istilası uğradığı yerlerde bir yıkımı beraberinde getirirken Anadolu, kısa zamanda onların önünden ve zulmünden kaçan bilim ve sanat erbabı kişilerin akınına uğradı. Bu zamanda Selçuklu devletinin hüküm sürdüğü Anadolu siyasi, iktisadi ve sosyal bakımdan müreffeh bir dönemi yaşamaktaydı. Fakat çok uzun bir zaman geçmeden Moğol istilası Anadolu'yu da etkisi altına aldı ve burada da kargaşa ve belirsizlik dönemi başladı.

Mevlâna Celâleddin Rumi bu dönemde yetişti. Bu kargaşa döneminde Mevlana ve çağdaşı olan ulema, günlük siyasi ve sosyal çekişmelerin içine girmektense kendi iç dünyalarına yönelerek, güzellikleri keşfetmeye yöneldiler. Bilim ve tasavvufi faaliyetler bu dönemde artmaya başladı. Daha sonra İslam dünyasının temel dinamiklerini oluşturacak olan Hac Bektaş-1 Veli (öl. 1270), Yunus Emre (öl. 1320), Sadrettin Konevi (öl. 1274), İbn-i Arabi (öl. 1240), Necmüddin Daye (öl. 1256) ve Fahreddin Iraki (öl. 1280) gibi âlim ve tasavvufi şahsiyetler Mevlâna (öl. 1273)'nın çağdaşı olarak bu asırda yetişmişlerdir ${ }^{3}$. Moğol istilasının uğradığı diğer bölgelerde sosyal ve kültürel canlılık durma noktasına gelirken, Anadolu'da gelecek yüzyllara da hayat verecek derecede bir kültür, eğitim ve tasavvufi hayatın gelişmesi ve olgunlaşması ancak Anadolu Selçuklu devletinin sahip olduğu iktisadi, kültürel zenginlik ve eğitimle açıklanabilir. Yine diğer bir önemli etken de bir yıkımı beraberinde getiren Moğolların önüne kattığı kitlelerden eğitim, sanat ve kültür erbabı elit bir zümrenin Anadolu Selçuklu devleti sahasını mesken

2 Hülya Küçük, "Sultan Veled'in İbtida Name'sine Göre Mevlevi Halifeleri”, http://www.mevlana.selcuk.edu.tr/belge/sumam-bildin-III/bildin-III-pdf/B10\%20Hulya\%20Kucuk.pdf.

${ }^{3}$ Osman Horata, "Mevlana ve Divan Şairleri", Hacettepe Universitesi Edebiyat Fakültesi Dergisi, 1999 Özel sayisı, s. 44. 
edinmeleri, onların yaşadıkları ve öngördükleri tavsiyelerle bu süreci akıla bir şekilde değerlendirmelerine bağlanabilir.

Mevlâna Celâleddin Rûmî, devrinin ünlü ilim ve tasavvuf erbabı Burhaneddin Tirmizi, Şemsi Tebrizi, Kuyumcu Selahaddin ve Ahi Türkoğlu Çelebi Hüsameddin'in sohbetlerinde bulundu ve onlarla arkadaşlık yaptı. Daha sonraki dönemlerde Mevleviliğin temelini oluşturacak olan Mevlana'nın Mesnevisi onun sohbet arkadaşı Çelebi Hüsameddin tarafindan yazıya geçirilmiştir. Bunlardan sonra şeyhlik makamına geçen Mevlânanın oğlu Sultan Veled ile beraber Mevlevilik sistematik olarak bir bütünlük kazanmı̧ ve tasavvufi bir yaşam biçimi olarak yayılmaya başlamıştır ${ }^{4}$.

Sultan Veled, babası zamanında ve onun etrafinda oluşan sohbet halkası içinde iyi yetişmiş ve teşkilaţ̧ı bir kişiliğe sahipti. Bu nedenle onunla beraber etraf vilayet ve ülkelere mevleviliği yayacak ve yaşatacak halifeler gönderilmeye başlandı. Mevlevi postnişini etrafinda kümelenenler ve buranın müdavimleri eğitim, kültür ve ekonomik yaşam itibariyle toplumun elit unsurunu oluşturmaktaydılar. Bu nedenle Mevlevi Dergâhı'na devam edenler çoğu zaman toplumda eğitim, kültür, sanat, ticaret ve yönetim alanında temayüz eden şahsiyetlerdi. Mevleviliğin yayllmaya başlandığı bu dönemlerde dahi diğer tekke ve zaviyelerden işlev ve işleyiş bakımından farklılıkları dikkati çekmekteydi. Onların yüksek bir kültür düzeyine sahip olmalarının sonucu olarak etraf vilayet ve ülkelerde kurulan Mevlevi dergahları, şehirlerin, ülkelerin yöneticileriyle ve de üstün eğitim ve kültür düzeyine sahip, halifelerle rahatça temas kuran ve onların destek ve himayelerini gören kurum oldular.

Mesela, Mevlâna'nın torunu Ulu Arif Çelebi (öl. 1320) bu amaca yönelik yaptığı seyahatlerde Menteşeoğulları'ndan Mesut Bey, Aydınoğulları'ndan Şucauddin İnanç, İlyas ve Mehmed Beyler, Germiyanoğulları'ndan Ali Şiroğlu Yakup Bey ve Eşrefoğulları'ndan Mehmed Bey'le rahatça diyalog kurmuş ve Mevleviliğin yayılmasına zemin hazırlamıştır ${ }^{5}$.

Musiki, sema ve şïr eşliğinde iç dünyaya yönelerek, yaratan ile baş başa kalma ve huzur bulma anlayışı ile Mevlevilik, Osmanlı devleti ile beraber çok daha farklı bir atmosfere girmiştir. Osmanlı devletinde ilk

${ }^{4}$ Hülya Küçük, a.g.m., s. 88.

${ }^{5}$ Ahmet Yaşar Ocak, "Türkiye Tarihinde Merkezi İktidar ve Mevleviler ( (XIII-XVIII. Yüzyllar) Meselesine Kısa Bir Bakış", Türkiyat Araştrmalan Dergisi, S. 2, (Mayıs 1996) s. 19. 
Mevlevi Dergâhı, II. Murat (1421-1451) döneminde başkent Edirne'de açılmıştır. Bu tarihten sonra Mevlevi Dergâhları Osmanlı padişahları başta olmak üzere, eğitim, kültür ve sanat erbabının rağbet ettiği bir yer olacaktır. Mevlevi tekkeleri Osmanlı devletinin gelişmesine paralel olarak şehirler, kasabalar ve köylere varıncaya kadar yaygınlık göstermiştir. Daha önceki dönemlerde olduğu gibi Mevlevi tekkeleri elit kültür düzeyine sahip insanların toplandiğı bir mekân olmuştur. Bu nedenle mevlevihâneler, Osmanlı divan şairlerinin yetiştikleri, müdavimi oldukları veya ilham aldıklan yerler olacaktır ${ }^{6}$.

Anadolu'nun Türkleşmesinde olduğu gibi, Balkanların Türkleşmesi ve İslamlaşmasında da diğer tarikatlar gibi mevleviliğin büyük etkisi olmuştur. Hemen hemen tüm Balkan şehirlerinde açlan mevlevihâneler, eğitim ve kültürel etkinlikleriyle burada yaşayan insanların ilgi odağı olmuştur. Osmanlı devlet yönetimi, büyük bir etkiye ve taraftara sahip Bektaşilik ile Mevleviliği dengede tutmaya çalışmıs ve birine karşı diğerini tercih etmemiştir. Devlet, takip ettiği politika gereği diğer tarikatlarda olduğu gibi, mevlevihânelerin işleyişine, bazı dönemlerde ortaya çıan çekişmeler hariç müdahale etmemiştir. Mevlevihanelere şeyh tayini ve azillerinde, merkezleri Konya'da bulunan çelebilerin işine karışmamıştır. Mevlevihaneler, vakıf statüsü altında gelirleri, harcamaları ve görevlileri tayin ve azilleriyle kendi içlerinde bağımsız hareket eden bir yapı arz etmekteydi.

Osmanlı devletinin Anadolu, Rumeli, Hicaz ve Afrika'sında teşkilatlanan mevlevihâneler, gerileme ve çöküs sürecine paralel olarak köylerden şehirlere doğru çekilmeye başlamışır. Meşihatın babadan oğula geçmesi ve vakıf gelirlerinin azalması gibi sıkıntılar sonucu olarak mevlevilikte 19. asırdan itibaren bozulmalar baş göstermiş; ilimde, sanatta ve musikide temayüz eden Mevlevilerin sayısı azalmaya başlamışır ${ }^{7}$.

\section{B- Samsun Mevlevihanesi}

Ulu Arif Çelebi'nin (1272 - 1320) şeyhliği döneminde Anadolu'da, Samsun'a yakın yöreler olan Tokat ve Amasya'da mevlevihânelerin açıldığı bilinmektedir. Samsun'da ilk Mevlevi tekkesinin ne zaman açıldığını şu andaki bilgilere göre net olarak ifade etmek mümkün değildir. Fakat değişik dönemlerden elde edilen bazı ipuçları ile bu konuda fikir

\footnotetext{
${ }^{6}$ Horata, a.g.m., s. $46-47$.

${ }^{7}$ Sezai Küçük, “Örnek Bir Mevlevi: Üsküdar Mevlevihanesi Son Postnişini Ahmed Remzi Dede (Akyürek)”, Ùsküdar Sempozyumu IV, (3-5 Kasım 2006) s. 644.
} 
yürütebilmekteyiz. Arif Çelebi'den sonra meşihat makamına geçen Abid Çelebi zamanında Konya'yı Karamanoğulları'ndan geri alan (1320) İlhanh hükümdarı Ebu Said Bahadır Han, Anadolu genel valisi olarak oğlu Timurtaş'ı görevlendirmişti. Timurtaş'in bu göreve gelmesinden sonra Anadolu'da çok kişinin yaptŭg gibi isminin sonunda "mevlev" olan Evha b. Muhammed'in yapturdığı camiyi ona ithaf etmesi, Samsun'da da Mevlevilerin veya bir mevlevihânenin olduğu düşüncesini akla getirmektedir ${ }^{8}$. Samsun, bu sıralarda iç bölgelerdeki şehirler kadar faal bir sosyal ve iktisadi hayata sahip değilse de çevreyle irtibatı sağlayan orta ölçekte bir kentti. Rum ve Ermeni nüfusun yanında önemli ölçüde Müslüman bir nüfus da bulunuyordu. Bu nedenle Anadolu'nun her tarafina yayılan Mevlevilerin, Emir Timurtaş döneminde Samsun'da da bir topluluk oluşturmuş olmaları çok muhtemeldir.

Mevlâna ve Mevlevilik ile ilgili çok değerli çalısmaları olan Abdülbaki Gölpınarlı, Osmanlı devletindeki mevlevihâneleri asitane ve zaviye olarak ikiye ayırmakta ve imparatorluğun tamamında, köylerdekiler hariç 14 asitane ve 76 zaviye statüsünde mevlevihânenin olduğunu söylemektedir. Bu bilgilere göre Samsun, zaviye statüsünde mevlevihânenin bulunduğu 76 merkez arasında gösterilmektedir ${ }^{9}$. Gölpınarl, bu bilgilerin hangi tarih itibariyle olduğunu bildirmemiştir, fakat biz bunun en azından 16 . yüzyıl ortalarından sonraki tarihlerde olduğunu tahmin ediyoruz. Çünkü 1520 tarihli tahrirde Samsun'da sadece Seyyid Kutbüddin, Hızır Paşa ve Ahi Evran zaviyelerinden bahsedilirken, mevlevihâne ile ilgili bir bilgiye rastlanılmamaktadır. Ancak 1576 tahririnde bu üç zaviye ile İsa Baba, Ahi Ali, Ahi Elekçi zaviyelerine ilaveten mevlevihaneden bahsedilmektedir. Bu nedenle Samsun'da ilk Mevlevi dergâhının 16. asrın yarılarında (1550- 1576) teşekkül ettiğini var saymaktayız ${ }^{10}$.

Bu bilgilerin dışında 19. yüzyıl yarılarına kadar Samsun Mevlevihanesi ile ilgili şu ana kadar bir malumata rastlanılamamıştır. İleriki zamanlarda Başbakanlık Osmanlı Arşivi, Vakıflar Genel Müdürlüğü Arşivi ve Konya Mevlâna Müzesi Arşivi'nde yapılacak detaylı araşturmalar sonucu ortaya çıkacak belgeler ve bilgiler elbette bu durumu değiştirebilir.

\footnotetext{
${ }^{8}$ Yakup Şafak, "XIX.- XX. Yüzyıllarda Samsun Mevlevihanesi", Gę̧mişten Geleceğe Samsun II, Edit: Cevdet Ylmaz, Samsun, s. 465.

${ }^{9}$ Abdülbaki Gölpınarl, Mevlanadan Sonra Mevlevilik, İstanbul 1953, s. 334-335.

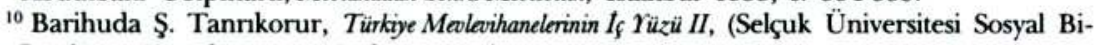
limler Enstitüsü Yayınlanmamış Doktora Tezi), (Konya 2000), s. 388.
} 
1852 yllından itibaren Samsun Mevlevihânesi ile ilgili bilgilere rastlamak mümkündür. Merhum tarihçi Nejat Göyünç, Barihuda Tanrikorur ve Sezai Küçük'ün Konya Mevlâna Müzesi Arşivi'nde yaptıkları araştırmalardan, 1852 yılında Samsun'da zaviye statüsünde bir mevlevihanenin olduğu anlaşılmaktadır. Mevlevihane şeyhi, Mustafa adında birisidir. Kale içinde de mevlevihaneye ait bir hamam bulunmaktadır ${ }^{11}$. Bu tarihte mevlevihanenin Samsun'da çok sönük ve faal olmadığı sanılmaktadır. Çünkü bundan on yll sonra Samsun'a müfettişlik görevi için gelen Bursalı Rıza Efendi, mevlevihânenin yerini sorduğunda hiç kimsenin bilmediğini görmüştür. Halka yönelik sosyal bir kuruluş olan bir binanın on yılda tamamen unutulması ve yerinin kaybolması akla pek uygun gelmemektedir. En azından bunun varlığına şahit olanların bulunması gerekirdi. Bu durum 1852 yllnda var olduğu kayıtlarda görülen mevlevihânenin pek işlevi kalmamış ve ilgisizlikten kaybolma aşamasına gelmiş olabileceğini tahmin ettiriyor ${ }^{12}$.

Osmanlı belgelerine göre 1857 yılı Mayıs ayında Samsun Mevlevihanesi şeyhliğine Antalyalı Hasan Dede'nin tayin edildiği görülmektedir. Bu tarihten sonra Samsun Mevlevihanesi ile ilgili kronolojik bilgilere ulaşmak mümkündür ${ }^{13}$. Hasan Dede'nin, Konya postnişinliği tarafindan Samsun Mevlevihânesi'e tayini ile Osmanlı devletinin sonuna kadar bu aile içinde babadan oğula intikal eden bir şeyhlik süreci başlamıs oldu. Bilinen diğer bir husus ise ailenin peygamber soyundan gelmesi ve "seyyid" olarak adlandırılmasıdır. Hasan Dede, Samsun'a geldikten sonra, sadece adı olan fakat binası ve yeri kalmayan mevlevihaneyi açmak üzere yer araştırmaya başladı. Hasan Dede'nin yer arama işini ya yavaştan aldığı veya bu noktada sıkıntı çektiği sanılmaktadır. Çünkü onun Samsun'a gelişinden 3 yll sonra, 1860 yllında hâlâ yer arayısıı devam etmektedir. Yer tespiti noktasında ilkönce tek seçenek olarak görülen Molla Fahreddin Zaviyesi üzerinde durulmuştur. Molla Fahreddin Zaviyesi'nin bu siralarda bina olarak ayakta olduğu fakat faal bir hâlde bulunmadığı sanılmaktadır ${ }^{14}$.

" Bu bilgiyi veren araştırmaclar Konya Mevlana Müzesinde bulunan ayn belgeleri görmüşlerdir. Nejat Göyünç, "Das Mevlevihane in Samsun", The foumal Ottoman Studies, XIV, (Istanbul 1994), s. 78; Barihuda Ş. Tannkorur, a.g.e., s. 388; Sezai Küçük, Mevleviliğin Son Yüzgnl, İstanbul 2007 , s. 250; Yine bu yazarlara dayanarak keza Şafak, a.g.m., s. 466.

${ }^{12}$ Göyünç, a.g.m., s. 388.

${ }^{13}$ BOA. A. MKT. UM. 280 / 87, (8 Ramazan 1273)

${ }^{14}$ BOA. MVL 595 / 50, (03 Şaban 1276) 
Molla Fahreddin Zaviyesi'nin mevlevihane olarak kullanımı yönündeki düşüncelerden bir sonuca gidilemedi. Buna yerel idari birimlerin veya zaviyenin muhtemelen ortaya çıkan muhiplerinin karşı çıtığı sanılmaktadır. Bu gerekçelerle olsa gerek Osmanlı devletinin sonuna kadar bu zaviye en azından bina olarak varlığını korumuştur. Uzun arayışlar sonucunda Mayıs 1862'de vaktiyle mescid yapmak üzere terk olunan, boş duran ve şehir merkezinde "musalla mevkii" olarak bilinen arazi tespit edildi ve buraya mevlevihâne yapılması konusu gündeme geldi. Bu konuda hukuki ve diğer engellerin olup olmadiğı konusunda gerekli yazışmalar ve araştırmalar yapılmaya başland $1^{15}$.

Küçük'e göre, Hasan Dede buraya tayin edildikten sonra musalla mevkiinde bir mevlevihane binası inşa etmek üzere harekete geçmiş ve binayı bitiremeden ölünce yerine 1864 yllında oğlu Hafiz Ali Dede tayin edilmiştir ${ }^{16}$. Fakat, Vakıflar Genel Müdürlüğündeki tafsil kaydına ve Tanrıkorur'a göre 1862 yllında Samsun Mevlevihanesi şeyhi olarak Hafiz Ali Dede gösterilmekte ve Hasan Dede'den bahsedilmemektedir. Bunlardan, 1857 ylında Antalyalı Hasan Dede'nin Samsun Mevlevihanesi şeyhliğine atandığı ve yer tespiti sürecinde vefat ettiği, yerine oğlu Hafiz Ali Dede'nin tayin edildiği anlaşılmaktadır. Yukarıda teftiş ile görevlendirildiğini söylediğimiz Bursalı Rıza Efendi' nin bu sıralarda Samsun'a geldiği tahmin edilebilir. Samsun Mevlevihânesi'nin 1852 y1lındaki şeyhi Mustafa Dede'nin, 1862 yllında mevlevihânenin ikinci kurucusu olarak kabul edilen Antalyalı Hasan Dede ile irsî bir bağının olmadığı sanılmaktadır. 3 Ekim 1911 ylında görevinden azledilen ve az sonra da ölen Samsun Mevlevihanesi şeyhî Enver Ali Dede'nin annesi Zeliha Hanım'ın, mevlevihaneye vekil şeyh olarak atanan Hüseyin Hasib Dede ile mevlevihaneye ait evi boşaltma ve kira gelirlerini teslim etme hususundaki tartışmalar esnasında Dâhiliye Nezaretine gönderdiği arzuhali bu konuda bize ipuçları vermektedir. Zeliha Hanım arzuhalinde Samsun Mevlevihânesi'ne ait ev konusunda "ceddimizin inşa ve ihya ettiği ve 60 seneden beri onun evlatlarnn kullandiğ " ifadelerine yer vermektedir. Buna göre 60 sene önceleri olarak ifade edilen zaman dilimi 1860'lara rastlamaktadır. Bu zaman ise Antalyah Hasan Dede'nin Samsun'a ilk geldiği tarihlere tekabül etmektedir ${ }^{17}$.

${ }^{15}$ BOA. A. MKT. MVL. $146 / 91$, (23 Za 1278).

${ }^{16}$ Küçük, a.g.e., s. 250.

${ }^{17}$ BOA. DH.ID. 84 (17)2-2, Zeliha Hanım'dan Dahiliye Nezaretine arzuhal (20 Eylül 1327) 
Hafiz Ali Dede, babası Antalyahı Hasan Dede'nin ölümü üzerine 1862 ylında Samsun Mevlevihanesi şeyhi olarak atandığında üzerinde mevlevihane vakfinın tevliyeti vardı fakat mevlevihâne vakfi olarak bir binası ve yeri yoktu. Bu durum öteden beri Samsun Mevlevihânesi vakfinın var olduğunu ve zamanla yerinin kaybolduğunu göstermektedir. Hafiz Ali Dede iki-üç hücreli bir vakıf binası yapmak üzere Samsun Mutasarrıflğına müracaat etti. Mutasarrıfllk, tevliyeti var olan fakat neresi olduğu bilinmeyen mevlevihâne binası için sahil üzerinde bulunan ve bu sıralarda terk edilmiş bir halde olan "Musalla" mevkiinde boş bir arazi ile metruk bir binayı yer olarak gösterdi. Bu yer, Hasan Dede'nin ölmeden önce tespit ettiği yerdir. Mahkeme kararıyla da Hafiz Ali Dede üzerinde olan vakfin adresi ve yeri olarak burası gösterildi. Samsun Mevlevihanesi'ne buranın verilmesinin bir sebebi de arazinin kaybolmaması ve işgalden önlenmesine yönelikti. Musalla denen yer metruk bir alan olup, burada mihraptan başka yeri kalmamıs bir bina bulunmaktaydı. Musalla'daki boş arazinin bir kısım yeri zamanla Avusturya Konsolosluğu tarafindan işgal edildiyse de daha sonra geri alınmışt. Mutasarrıflıkça arazinin bir kısmına mevlevihâne yapılması izni verilirken, kalanı da yine boş alan olarak kalacaktı. Etrafta ise Avusturya Konsolosluğu, Rusya Konsolosluğu, Pestere'nin bağı ve ana cadde bulunmaktaydı. Arazinin korunması için etrafi parmaklıklarla çevrilen Musalla'daki 3075 zira' $\left(1583,5 \mathrm{~m}^{2}\right)$ arazinin 2625 zira'ı $\left(1282 \mathrm{~m}^{2}\right)$ mevlevihaneye ait olacakt. Hafiz Ali Dede, buraya bir mescid, tevhidhane ve ev yapacaktı ${ }^{18}$.

1862 yllında mevlevihane binasının inşasına ve etrafinın düzenlenmesine başlandı. Binanın yapımı ve hizmete girmesinin iki yll bulduğu sanılmaktadır. Çünkü 1864 ylında kendisi de mevlevi olan müfettiş Bursalı Rıza Efendi, yapım sürecinde olan rüşdiye mektebi ve İsa Baba minaresinin inşaatlarını teftiş görevi ile ilgili Samsun'a geldiğinde, henüz faaliyete geçmeyen mevlevihânenin camisini, caminin minaresini ve şeyhefendi dairesinin teftişini de yapmışır ${ }^{19}$. Bu teftişten sonra mevlevihânenin hizmete girdiği kesindir. Çünkü 1865 yll Aralık ayında

18 VGMA (Vakfflar Genel Müdürrlügü Arşivi) Defter no: 304, sh. 32 (2 Rebi'ul-evvel 1279 tarihli tafsil kaydı) (Samsun Vakıflar Bölge müdürlüğünde de bu tafsil kaydının sureti mevcuttur). Musalla denen yer bugün Cumhuriyet meydanının yan tarafinda Tekel binalan ile İl Özel İdaresi binası arasındaki yerdir. Bu arazinin bir kısmı şu an açik otopark olarak kullanimakta ve kalan kısminda ise "Mevlevihane caddesi" geçmekte ve cadde üzerinde binalar bulunmaktadır.

${ }^{19}$ BOA. MVL $674 / 40$, (08. Z. 1280) 
Şeyh Seyyid Hafiz Ali Dede'nin, mevlevihânenin "taamiye-yemeklik" tahsisatının arttırılması için müracaat ettiği görülmektedir ${ }^{20}$.

Hafiz Ali Dede'nin 1867 ylında öldüğü bilinmektedir. Onun, mevlevihâne şeyhliğinde kaldığı beş yıl içinde mevlevihânenin yapıldığı ve faaliyete geçirildiği kesindir. O ölünce yerine 10 Ağustos 1867'de oğlu Cemaleddin Efendi (veya Cemal Efendi) atanmıştır. Yeni şeyh atandığında mevlevihane 3-4 yllık bir geçmişe sahipti. Bu nedenle göreve başladığı tarihten itibaren mevlevihâneyi geliştirmek için gayretler gösterdi. Yeni yapılan mevlevihâne kargir ve bir semahane ile birkaç hücreden oluşuyordu. Eski mevlevihâneye vakfedilen köylerin öşür gelirleri Maliye Nezareti tarafindan yeni mevlevihâneye aktarldd ${ }^{21}$.

1869 yll Ağustos ayında Samsun'un neredeyse tamamını kül haline getiren bir yangın çıktı. Bu yangından mevlevihânenin de etkilendiği muhakkaktır. Bu asırda, zengin bir ticaret kenti olan Samsun yang1nın yaralarını çabucak sarmayı başarırken, Fransa'dan getirilen mimarın planına göre caddeler ve sokaklar yeniden düzenlenerek yeni binalar yapıld $\mathbf{1}^{22}$. Babasının vefatıyla mevlevihâne şeyhliğine gelişinin ikinci yılında çıkan bu yangından sonra Cemaleddin Efendi, mevlevihâneyi tamir ettirdi. Fakat bu tamir pek kolay olmayacaktur. Gerek yangin ve gerekse doğal eskime sürecinde, yanında bulunan camii ve minarenin bazı yerleri bozulmuş ve dergâhı çevreleyen duvarlar yıkılmaya yüz tutmuştu. Yapılan tespitler 5.610 kuruş tutarında bir tamirat masrafi gerektiriyordu. Bu meblağı karşılayacak kadar dergâhın bir geliri yoktu. Yıllık 1.200-1.800 kuruş arasında olan gelir ise gündelik masraflar ve ihtiyaçlara ancak yetiyordu. Şeyh Cemaleddin Efendi, tamiratı gerçekleştirmek için Canik Idare Meclisinden çıkarttığı bir kararla Ekim 1873 yllında Evkaf Nezâretine müracaat ederek yardım talep etti. Fakat bu dönemde, devletin mali sıkıntılar içinde bulunması sebebiyle talebe olumlu cevap verilmesi çok zor görünüyordu. Nitekim bu talebe olumlu ve olumsuz hiç bir cevap almak mümkün olmadı. Duyûn-ı Umûmiye'nin ilanı ile de merkezî hazineden bu tür masraflara ödenek ayırmak daha zor hale geldi. Cemaleddin Efendi'nin yaptığı müracaattan 19 yl sonra 1891 yllında evrak, mürur-1 zamana uğradığı şerhi konularak mahzene kaldırılmışıı ${ }^{23}$.

${ }^{20}$ BOA. MVL 487 / 58, (25 B. 1282)

${ }^{21}$ Tanrikorur, a.g.e., s. 389.

${ }^{22}$ Besim Darkot, "Samsun", Islam Ansiklobedisi (LA), 10, İstanbul 1988, s. 176.

${ }^{23}$ BOA. EV. MKT. 1683 / 105. Evkaf-1 Hümayun Nezaret-i Celilesine (18 Teşrin-i evvel 1289). 
Samsun Mevlevihanesi, yol üzerinde ve faal bir konumda olduğu için Cemaleddin Efendi, kendi imkânlarıyla bu tamiratı gerçekleştirmeye çalıştı. Fakat bu tamir de kolay olmayacak ve Cemaleddin Efendi, ekonomik olarak çok sıkıntılar yaşayacaktır. Daha önceki müracaatına cevap alamamasına rağmen onun 1887 ylında tekrar Nezarete yardım için müracaat ettiği görülmektedir. Bu sefer de dergâhın iki yıllık gelirinden ellerinde 2530 kuruş paralan olduğu vurgulanarak 6.000 kuruş talep edilmektedir. Fakat gelen cevap kesin olarak olumsuzdur ve "masrafi karşlayacak kadar paralan olduğunda" dergâhı tamir ettirmeleri tavsiye edilmektedir ${ }^{24}$.

Cemaleddin Efendi, yaptı̆̆ı müracaatlara cevap alamayınca tamiratu kendi şahsi imkânlarıyla yapmaya teşebbüs etti. Zengin bir ailenin kızı olduğu sanılan eşi Zeliha Hanım'dan aldığı borçla tamiratı gerçekleştirmeye çalışt. Kayınpederinden miras yoluyla kalan araziyi Ziraat Bankasina ve Aksaray'da bulunan kendi dairesini de Suyolu Vakfi'na rehin bırakarak ihtiyacı olan meblağı buralardan karşılamıştır. Dergâhta hem tamirat hem de dergâha bazı ekler yaptırdı. Mevcut hücrelerin üzerine üç odalı bir selamlık ve bir de harem dairesi inşa ettirdi ${ }^{25}$. Cemaleddin Efendi 27 ylla yakın süren görevi esnasında ahali tarafindan sevilmiş ve Samsun'da çok sayıda kişinin Mevleviliğe intisabını sağlamıştır.

Cemaleddin Efendi 1893 yllında ölünce yerine 7 yaşındaki oğlu Ali Enver Dede geçti. Fakat onun yaşı küçük olduğundan kendisine Gelibolu Mevlevihanesi çilekeşlerinden Laz Mehmet Efendi vekil tayin edildi. Laz Mehmed Efendi'nin Samsun'a geldiği yllarda Samsun inhisar idaresine ait tütün fabrikası bitişiğinde bulunan mevlevihânenin müdavimlerinin kalabalık olduğu sanılmaktadır. Zira Cemaleddin Efendi'nin gayretlerinin yanında bununda payı olduğu açıktır. 1893 ylında Samsun'dan geçen V. Fottwell bu yıllardaki Samsun'u tasvir etmektedir. Ona göre 2.624 ev bulunan Samsun'da Türk, Frenk ve Rumlar yaşamakta; Frenkler sahilde, Rumlar tepede (Kadıköy) ve Türkler de ikisinin arasında oturmakta ve tütün fabrikasında da 600 işçi çalışmaktay$\mathrm{d}^{26}$. Bu dönemde Samsun, gittikçe büyüyen ve canlanan bir şehirdi. Bunun bir göstergesi olarak Bağdat yolunun başlangıcı olmasından dolayı yabancı tebaalı tüccarlar ve yolcular sıkça Samsun'a uğramaya ve iş gereği yerleşmeye başlamışlardı. Bunların başında Samsun'da gittikçe

\footnotetext{
${ }^{24}$ BOA. EV. MKT. 1400 / 13, Trabzon vilayeti Evkaf Muhasebeciliğine (30 Teşrin-i sani 1303).

${ }^{25}$ Küçük, a.g.e., s. 251.

${ }^{26}$ Darkot, a.g.m., s. 176.
} 
artan İranlıları görmek mümkündür. Bu çoğalmanın sonucu olarak 1893 yllında yapımına göz yumulan "Hüseyniye Tekkesi (Camii) / Acem Tekke$s i$ "'nin faaliyete geçmesi, Samsun'daki sosyal ve kültürel hayatın gittikçe zenginleşmeye başladığının göstergesidir ${ }^{27}$.

Cemaleddin Efendi zamanında mevlevihânenin faaliyetleri ve işlevi devam ettirilmiştir. Bu dönemde de mevlevihâne giderleri çok olduğundan yıllık gelirlerinin artırılması için sürekli Evkaf Nezaretine müracaat edildiği görülmektedir ${ }^{28}$. Laz Mehmed Efendi, zamanla mevlevihânede ortaya çıkan eksiklikleri gidermeye çalışarak faal halde tutmaya gayret göstermiştir. Mesela mevlevihâne binasında uzun zaman süren bir tamirat yaptırmış, bitince de 22 Mayıs 1901 Cuma günü Samsun mutasarrıfi, yöneticiler, ulema ve halkın katılımıyla oluşan bir törenle tekrar hizmete açılmışır ${ }^{29}$.

Ali Enver Dede ancak 18 yaşına girince 1904 ylı başlarında Samsun Mevlevihânesi'ne asaleten atandı. Aynı yll çıkan yangında dergâhın bütün müştemilatı yandığından Ali Enver Dede'nin annesi Zeliha Hanım, mevlevihâneyi kendi geliriyle yeniden yaptırmak istedi. Bunun için Hançerli Mahallesi'nde babasından miras olarak kalan evi Samsun

${ }^{27}$ BOA. DH. MKT. 140 / 32 ( $14 \mathrm{Ra} 1311$ ). Samsun limanının dış dünyaya açlımda önem kazanması ve yine buradan başlayarak Anadolu'dan Bağdat'a kadar ticari yolun ehemmiyet kesbetmesi üzerine İran devleti 1859 yılında Samsun'da olan tebaasına ait kişilerin hususi ve ticari işleri ile ilgilenmek üzere İranlı tüccar Yusuf Ağa'yı yetkili olarak gösterdi. Aynı yıl İran, diğer ülkelerin konsoloslukları gibi bir şehbenderlik açmak için Osmanlı makamlarına müracaat etti. 1861 yllında bir ara Samsun'daki İranh tüccarlarnn işlerine İngiltere konsolosluğunun baktığı görülmektedir. Bu tarihlerden sonra İran şehbenderliği (Karperdaz) bulunmakla beraber 1890'lardan sonra çok daha faal hale gelmiştir. Birinci Dünya Savaşı yllannda Amerika, Rusya, Íngiltere, Fransa, Romanya, İtalya, İspanya, Portekiz ve Karadağ tebaalarının Samsun'daki işleri İran Karperdazı tarafindan yürütülmüştür. Samsun'daki İran karperdazlığ 1891 ylında "Hüsgyniye" adıyla bir tekke=cami açılması müracaatı yapmıs fakat bu kabul edilmemişti. Aradan geçen iki yl sonunda bu tekkenin gayr-1 resmi kaçak olarak inşa edildiği görülmektedir. Bu yapıma Samsun yerel yöneticilerinin müsamaha gösterdikleri açıktır. Fakat yapıldığı tarihten itibaren Samsun halkı bu tekkeye karşı hiç de sıcak bakmamışur. Hizmete açilması ile beraber yıkılması için yerel halktan mücadele edenler olmuş fakat devlet hizmete devam etmesi yönünde karar vermiştir. Samsun'daki İranlılara ait olan, açıldığında "Hüseyniye" ve daha sonraki yıllarda da "Acem" adiyla anılacak olan tekke Osmanlı devletinin sonuna kadar devam etmiş ve 1925 yllında kapatılmışur. Acem tekkesi bu gün Büyükşehir Belediyesi'nin kuzeyinden geçen Bulvar yolu üzerinde, restorasyonunu yaparak onu yıkılmaktan kurtaran İkadım Belediyesi uhdesinde "kafe" olarak varlı̆̆ını sürdürmektedir. Samsun Acem Tekkesi ve Samsun İran Şehbenderliği ile ilgili tarafimdan yapılacak olan bir çalışmada bu konu detaylı bir şekilde işlenecektir.

${ }^{28}$ BOA. DH. MKT. 2096 / 10 (1316); BEO. 1184 / 88760 (1316).

${ }^{29}$ Ikdam, 9 Mayıs 1317, sayı: 2481 "Samsun'dan yazılıyor" başlıklı haber (22 Mayıs 1901). 
ahalisinden Rıfat Bey'e rehin olarak vermiş; buradan aldığı 120 lira, evin bitişiğindeki arsayı satarak elde ettiği 30 lira ve dergâhtaki yangın sırasında harap olan eşyanın sigortalı olmasından dolayı aldığı 200 lira olmak üzere toplam 350 lira ile dergâh arsası üzerindeki hücreler mahalline sekiz adet dükkân ve dergahın bitişiğindeki arsaya da altında iki dükkan ve üstünde dört odalı bir bina inşa ettirmiştir. Yani Zeliha Hanım yanan dergâhın hücreleri üzerine bir ev ve geçimini temin için ise on adet dükkân inşa etmiştir. Ali Enver Dede ve annesi Zeliha Hanım dergâh müştemilatını yenilerken ve ekler yaparken geri kalan semahane harap durumda kalmışır ${ }^{30}$.

Ali Enver Dede döneminde Samsun Mevlevihânesi, 1904 yllında çıkan yangından sonra pek faal görünmemektedir. Her ne kadar o asaleten şeyh olarak görünüyorsa da annesi Zeliha Hanım tüm işleri halletmektedir. Mevlevihâne bir nevi kişisel mülkleri gibi kullanılmaktadır. Zeliha Hanım'ın yangından sonra mevlevihâne müştemilatına Konya'dan izin almadan ev ve dükkânlar yapması ve bunların kira gelirlerini toplaması bunu göstermektedir. Mevlevihâne'nin semahane kısmı da muhtemelen kısmen tamir edilmiş olmalıdır. 1904 yılı öncesine bakıldığında bu kısım çok harap kalmışur. Bu nedenle Ali Enver Dede'nin şeyhliği döneminde Samsun Mevlevihânesi sönüktür ve faal değildir. Bu yüzden Konya'da bulunan Mevlana postnişinliği Ali Enver Dede'yi "vezaif-i meşihat ifa etmediği ve 'adem-i iktidar ve safahata" düşkünlüğünü gerekçe gösterilerek 1911 yılı başlarında (muhtemelen Mart-Nisan ayı) görevinden azletti ve yerine Çankırı dergâhından Hüseyin Hasib Dede vekaleten tayin edildi. Ali Enver Dede'nin görevden azledilmesinde sefahata düşü̈n yaşamı sebebiyle onun aleyhine Samsun'dan giden şikayetnâmelerin de etkisi olduğu sanılmaktadır ${ }^{31}$.

Ali Enver Dede görevinden azledildiğinde 25 yaşlarında genç biriydi. Toplum içinde örnek davranışlarda bulunması ve mevlevi örf ve adabına riayet etmesi gereken birinin sefahata düşkünlükle suçlanması bu dönemde örneği görülen olaylardı Zira Osmanlı devletinin son dönemlerinde diğer kurumlarda olduğu gibi Mevlevilikte de bozulmalar olmuştur. Ahmed Remzi Dede'nin Kudüs Mevlevihanesi şeyhi Muhammed Hilmi Efendi ile ilgili "Yirmi dört yirmi bes yaşlarnda olan şeyh bekârdir. Başındaki sikkesinden başka dervişliğine delaleteden bir hali olmayıp daha ģok nefsine ve hevâ ve

${ }^{30}$ Küçük, a.g.e., s. 252.

${ }^{31}$ BOA. DH.ID. 84 (17)2-2, Zeliha Hanım'dan Dahiliye Nezareti'ne arzuhal (20 Eylül 1327). 
hevesine tabi bir kişidir." "Kendisine sirretiyle sûretinin mütenasip olmasina gayreti için nasihatte bulunuldu" demesi bu dönemde mevlevihânelerin içinde bulunduğu durumu açıkça ortaya koymaktadır ${ }^{32}$.

Ali Enver Dede'nin annesi Zeliha Hanım, oğlunun bir komploya kurban gittiğini ve hiçbir araşturma ve soruşturma yapılmadan Çelebi Efendi tarafından görevinden uzaklaştırıldığını savunmaktadır. Ona göre oğlunun görevden uzaklaştırılması, Osmanlı devletinde gittikçe artan tezviratın Samsun'da da arttı̆ının bir göstergesidir. Bu tertibatın sonucu olarak hazırlanan bir mazbatanın Konya'ya ulaşmasından sonra soruşturma olmaksızın oğlu görevden alınmış bulunuyordu. Vekil şeyh olarak atanan Hasib Dede, 1911 yll Nisan ayında Samsun'a geldi ve görevine başladı. Fakat mevlevihâneye ait hane ve dükkân gelirlerinin Ali Enver Dede ve Zeliha Hanım tarafindan kendisine teslim edilmemesi üzerine olayı Samsun Mutasarrıflğına intikal ettirdi. Fakat bu arada 1911 yllının Temmuzunda eski şeyh Ali Enver Dede koleradan genç yaşta hayatını kaybetti. Zeliha Hanım, 90 yaşlarındaki kayınvalidesi, küçük yaşta olan çocukları Yusuf ve Safiye ile baş başa kaldı. Aşağıda anlatulacağı üzere bu sıkıntıların yanında Zeliha Hanım mevlevihâne ve müştemilatından elini çekmediği için vekil şeyh Hasib Dede ile uzun sürecek bir mücadelenin içine girdi. Daha doğrusu ömrünün büyük kısmını mevlevihâne içinde ve hizmetinde geçiren Zeliha Hanım, haksızlığa uğradıklarını düşünerek mevlevihâneden çıkmamaya ve direnmeye çalışacaktır ${ }^{33}$.

Hasib Dede'nin müracaatı üzerine Mutasarrıflık, Zeliha Hanıma yaptığı tebligatta 20 gün içinde mevlevihâneye ait ne varsa teslim etmesini istedi fakat bir netice alınamadı. Bu sefer Hasib Dede, durumu Konya'ya bildirdi. Konya Mevlana postnişini Veled Çelebi, Samsun Evkaf Memurluğuna telgraf göndererek Hasib Dede'nin kiralık evlerde kalarak perişan olduğunu ve mevlevihâne ile ilgili sorunun giderilmesine yardımcı olunmasını, mevlevihâne ve gelirinin işgalden kurtarılmasını istedi ${ }^{34}$. Diğer taraftan da Dâhiliye Nezareti kanalıyla Samsun Mutasarrıflı̆̆ nezdinde teşebbüse geçildi ${ }^{35}$.

${ }^{32}$ Küçük, a.g.m., s. 647.

${ }^{33}$ BOA. DH.ID. 84 (17) 2-2, Zeliha Hanım'dan Dahiliye Nezareti'ne arzuhal (20 Eylül 1327).

${ }^{34}$ BOA.DH.ID. 84 (17) 9, Canik Efkav memurluğundan mutasarnfllğa müzekkere (3 Ağustos 1327).

${ }^{35}$ BOA.DH.ID. 84 (17) 1-2, Çelebi Veled Efendiden Dahiliye Nezaretine (22 Ağustos 1327). 
Veled Çelebi'nin Samsun Evkaf Memurluğuna yaptı̆̆1 müracaat üzerine Canik Sancağı İdare Meclisi bu meselenin sonlandırılması yönünde bir karar aldı. 30 Eylül 1911 tarihinde Mutasarnf Mehdi Bey, Naib Ali Vahid, Nazif Efendi, Tahrirat Müdürü Hüseyin Hasan, Metropolid, Müftü, aza Besim, aza Naim ve aza Todoraki Eefendilerden oluşan Canik Sancağı İdare Meclisi tarafindan daha önce verilen 20 günlük mühlette mevlevihane müştemilatını teslim etmeyen Zeliha $\mathrm{Ha}$ nım’a bu sefer 5 günlük süre verilerek işgal ettiği yerleri boşaltması istendi. Eğer boşaltılmazsa polis zoruyla dışarı çıkarılacaklardı ${ }^{36}$.

Mutasarrıflık, Dahiliye Nezaretine konuyla ilgili gönderdiği yazıda da, eski şeyhin uygunsuz davranışları nedeniyle postnişinlik tarafindan görevinden alındığını yeni Şeyh Hasib Dede'nin görevinin başında ve mevlevihânenin açık olduğunu bildirmekte, eski şeyh ve annesi Zeliha Hanım'ın mevlevihânede hiçbir hakkı olmadığını belirtmekteydi. Buna göre Mevlevihane, en son geçirdiği yangında yanmıs ve mevcut durumuna temin ettiği borç paralar ile gelmişti. Bu borçlar da daha sonra vakıf gelirleri ile ödenmişti. Dolayısıyla eski şeyhin iddia ettiği gibi kendi özel gelirleri ile yapılmamışt ${ }^{37}$.

Meseleye Canik Mutasarrıflı̆̆, Konya Mevlana postnişinliği ve nezaretlerin el atması ve işin emniyete intikal etmesiyle zor bir sürece girdiğini gören Zeliha Hanım, bir taraftan mevcut Şeyh Hasib Dede ile anlaşma yolları ararken, diğer taraftan da hukuken mağduriyete uğradığını iddia ederek resmî makamlara müracaatlarda bulundu. Hasib Dede'ye Mevlevihâne gelirlerini ortak kullanmayı önermiş fakat olumsuz cevap almıştı. Dahiliye Nezaretine gönderdiği dilekçe ile de mağdur duruma düşürüldüğünü iddia etmekte ve bu konuda yardım talep etmektedir. Zeliha Hanım'a göre, meselenin mahkemeler tarafindan halledilmesi gerekirken, Canik Mutasarrıflı̆ının müdahil olması kanuna aykırıydı. Ona göre bu mesele Osmanlı devletinin yaşadı̆ı olumsuzlukların bir parçasıydı. Güzel hizmetler yapan oğlunun azledilmesi konusunda Çelebi Efendi'nin araşturma yapmadan verdiği yanlış bir karardı. Osmanlı toplumunun tamamında olduğu gibi bu olayda da henüz ilan edilen Meşrutiyet'ten çok şeyler beklenilmekteydi. Ona göre Meşrutiyet döneminde kanunsuz bir uygulama nasıl yapılabilirdi. Hele 90 yaşlarında bir anne ve iki yetimle sokakta kalmasına rıza gösterilecek miydi? ${ }^{38}$.

${ }^{36}$ BOA.DH.ID. 84 (17) 12, Canik Meclis-i İdare-i Livanın karan (17 Eylül 1327).

${ }^{37}$ BOA.DH.ID. 84 (17), Canik mutasarnfluğından Dahiliye Nezareti’ne (5 Teşrin-i evvel 1327).

${ }^{38}$ BOA. DH.ID. 84 (17) 2-2, Zeliha hanımdan Dahiliye Nezareti'ne arzuhal (20 Eylül 1327). 
Canik Mutasarrıflı̆g meseleyle ilgili idari birimleri bilgilendirirken $^{39}$, tanınan sürede mevlevihâne boşaltılmayınca Canik Polis Müdürlüğü Zeliha Hanım'ın evde olmadığı bir anda kapıyı kırarak eşyalarını tahliye etmiş ve Hasib Dede buraya yerleştirilmiştir. Bunun üzerine $\mathrm{Ze}$ liha Hanım "devr-i mesrrutiyette" ve mahkeme kararı olmaksızın girişilen bu zorla hane boşaltma olayını Canik Müdde-i Umumiliğine şikayet ederek meseleyi mahkemeye taşınmıştır ${ }^{40}$.

Canik Polis Müdürlüğü kayıtlarından, mevlevihânenin tahliyesi sürecinde yaşananları öğrenebilmekteyiz. Zeliha Hanım’a tanınan beş günün sonunda mevlevihâne müştemilatı boşaltılmayınca, polisler, evi mevlevihâne bitişiğinde olan Zeliha Hanım'ı zor kullanarak çıkarmaya çalıştılar. Daha sonraki gelişmelerden anlaşıldığı kadarıyla, Zeliha Hanım evden polis zoruyla çıkarılacağını anlayınca Samsun'da ona destek veren bazı devlet görevlilerinin telkiniyle evi bilinçli olarak terk etmiştir. Polisler kapıyı kırdılar ve içerde olan eşyaları heyet huzurunda kaydederek bir odaya koydular (18 Ekim 1911) ${ }^{41}$.

Bunun üzerine Zeliha Hanım, mahkeme kararı olmaksızın evinin kapısının polis memurları tarafindan kırılarak eşyasının dışarı çıkarıldığına yönelik Canik Müdde-i Umumiliğine şikâyette bulundu ${ }^{42}$. Bunun yanı sıra mahkeme kararı olmaksızın evinden tahliye edilmesini sağlayan Canik Mutasarrafi ve Meclis-i Idare Reisi Mehdi Bey, azalar Naib Ali, Muhasabeci Nazif, Tahrirat Müdürü Hüseyin Hasan, Samsun metropolidi, Ermeni murahhasları Besim, Naim ve Todorayani Beylerle kararı infaz eden Canik Polis müdürü Hayri Bey hakkında dava açıldı. Canik Müdde-i Umumiliği, olayı memuriyeti suistimal olarak görerek konuyu ayrıca Şura-yı Devlet Bidayet Müstantıklığına gönderdi' ${ }^{43}$.

Samsun Mevlevihanesi'nde bu gelişmeler olurken mevlevihâneye vekil şeyh olarak atanan Hasib Dede vazifesine devam ediyordu. Mevlevihâne, müteveffa Şeyh Ali Enver Dede zamanında yaşadığı atıl görüntüyü atlatmıs ve faal hale gelmiş bulunuyordu. Fakat eski şeyhin ai-

${ }^{39}$ BOA.DH.ID. 84 (17) 3, Canik Sancağ'ndan Dahiliye Nezareti'ne (8 Teşrin-i evvel 1327).

${ }^{40}$ BOA.DH.ID. 84 (17) 14, Ali Enver Dede validesi Zeliha Hanım'ın arzuhali (8 Teşrin-i sani 1327).

${ }^{41}$ BOA. DH.ID. 84 (17) 10-3, Canik polis komiserliğinden Canik Müdde-i Umumiliği'ne (8 Teşrin-i evvel 1327).

${ }^{42}$ BOA.DH.ID. 84 (17) 10-2, Canik Müdde-i Umumiliği'nden Canik Mutasarnfllğ'na (11 Teşrin-i evvel 1327).

${ }^{43}$ BOA.DH.ID. 84 (17) 8-3, Canik Bidayet Mahkemesi Müstantkkhğı'nın karanı (27 Teşrini evvel 1327). 
lesi 60 yıldır Samsun'da yaşadığından burada geniş bir çevre edinmiş bulunuyordu. Ortaya çıan bu meselede Zeliha Hanım'ın gerek Samsun ve gerekse İstanbul'dan destek aldığı ihtimal dâhilindedir. Zeliha Hanım, eski Şeyh Cemaleddin Efendi'nin hanımı ve ondan sonraki Şeyh Ali Enver Dede'nin de annesi olarak Samsunlularca çok iyi tanınan bir kadındı. Bu nedenle şehirde geniş bir nüfuza sahip olması sebebiyle yaşadığı sıkıntılardan çıkabilmesine yönelik destekçi ve yol gösterenleri vardı. Canik Mutasarrıflğı ve Polis müdürlüğünün aksine Samsun'da adli yargı ve birçok kurum Zeliha Hanım'a yardımcı oluyorlardi ${ }^{44}$. Onun evden çıkmaması ve polis zoruyla tahliyesi anında evi terk ederek olayı haneye tecavüz boyutu katarak mahkemeye intikal ettirmesi ona yol gösterenlerin olduğunu akla getirmektedir ${ }^{45}$. O dönemde Samsun'da yayımlanan Aksi Seda gazetesi de Zeliha Hanım'ın mücadelesini destekleyen ve Hasib Dede'yi yeren yayınlar yapmışı ${ }^{46}$.

Zeliha Hanım'ın şikâyetinden sonra mesele Canik Bidayet Mahkemesi, Dâhiliye Nezareti ve Şura-yı Devlet arasında birçok yazışmalara konu edildi. Ortaya çıkan yazışmalardan Canik Mutasarrıflığı suçlu olarak görülüyordu ${ }^{47}$. Dâhiliye Nezareti mutasarrıflı̆ın tasarruflarını onaylamasına rağmen Şura-yı Devlet Zeliha Hanım'ın mağdur edildiği görüşündeydi. Mutasarrıflık, yaptı̆̆ı savunmalarda, idarenin tüm livanın başı olduğu ve uygulamalarda eşit davranıldığını iddia etmiş ve idare meclisinde alınan kararın hayata geçirildiğini savunmuştur. Buna göre Şura-yı Devlet'in 1903 ve 1909 tarihli hayratları koruma yetkisinin mahalli yöneticilere ait olduğu kararı uygulanmıştır. Mutasarrıflık ayrıca mevlevi tekkesi ile ilgili kararı suç olarak gösteren Canik Bidayet Mahkemesini yanlı̧ karar vermekten dolayı Adliye Nezaretine şikâyet etmiştir ${ }^{48}$.

Mevlevihane'de şeyh değişimi sürecinde ortaya çıkan bu mesele yerel idari ve adli birimleri karşı karşıya getirmişti. Bu dönem, Trablusgarp savaşının devam ettiği ve Osmanlı yönetiminin tüm dikkatlerini Trablusgarp’a ve kargaşanın başladığı Balkanlara çevirdiği bir süreçti. Bu süreçte eski şeyhin validesi Zeliha Hanım gerek Samsun'da ve ge-

${ }^{*}$ BOA.DH.ID. 84 (17) 8 , Adliye Nezareti'nden Sadaret'e (12 Kanuin-1 evvel 1327).

${ }^{45}$ BOA.DH.ID.1332.R.4 Temyiz Müdde-i Umumiliği karan (10 Kanun-1 evvel 1327).

${ }^{16}$ Tanrikorur, a.g.e., s. 390 .

" BOA.DH.ID. 84 (17) 3-2 Dahiliye Nezareti'nden Canik Mutasarnfllğ'na (19 Kanun-1 evvel 1327). 1327).

${ }^{48}$ BOA.DH.ID. 84 (17) 7 Canik İdare Meclisi'nden Dahiliye Nezareti'ne (5 Kanun-1 sani 
rekse İstanbul'da mevlevihâneden tahliye edilmesini "haneye tecavüz" olarak kabul ettirmiş olacak ki 1912 yll Ocak ayında Dahiliye Nezareti, Canik Mutasarrıflğı ve Canik İdare Meclisini "muaheze eden" bir yazı gönderdi $^{49}$. Buna göre mutasarrıflığın tasarrufu hayrata saldırı olarak algılanmış fakat görevden kaynaklanan bir gelişme olduğu için de herhangi bir ceza açlmasına gerek görülmemiştir. Zeliha Hanım hukuk mücadelesinden başarıyla çıkmıs bulunuyordu ${ }^{50}$.

Eski Şeyh Ali Enver Dede'nin annesi Zeliha Hanım, Canik Mutasarrıfllğı ve İdare Meclisini suçlu duruma düşüren hukuk mücadelesini kazandıktan sonra 1912 yll içinde tekrar, mevlevihâneye ait eve taşındı. Samsun Mevlevihânesi ile ilgili çok hizmetler yapan fakat hukuki mücadeleyi kaybeden vekil Şeyh Hasib Dede, Samsun'dan ayrılmak zorunda kaldı ve Çankırı Mevlevihânesi'ne gönderildi. Ayrılırken yerine Ünyeli Mahir Efendizade Halil Efendi'yi vekil olarak bıraktı. Zeliha Hanım kaybettiği haneyi geri almakla kalmamıs, uygunsuz davranışları sebebiyle şeyhlikten azledilen ve az sonra da koleradan ölen oğlu şeyh Ali Enver Dede'nin yerine en küçük oğlu Yusuf Efendi'yi mevlevihânenin yeni şeyhi olarak atanmasını sağlamışt ${ }^{51}$. Yusuf Efendi'nin vekil şeyh olarak atanmasında annesi Zeliha Hanım'ın Konya Mevlana postnişinliğe sürekli mektuplar göndererek yaptığı baskının büyük rolü olduğu sanılmaktadır. Çelebi Efendi'nin yanı sıra İstanbul Yenikapı Şeyhi Abdülbaki Dede, Kasımpaşa Şeyhi Ali Dede, bu sıralarda müebbeden Kemah'a sürülen Kemahî İbrahim Hakkı Dede gibi nüfuzlu kişilerden de destek aramıştır $^{52}$. Yusuf Efendi'nin yaşı çok küçük olduğu için onun yerine Kastamonu Mevlevihânesi'nden Mehmed Emin Efendi vekil şeyh olarak atandı. Halil Efendi'nin muhtemelen Mehmed Emin Efendi gelinceye kadar 2-3 aylık bir süre kadar dergâh şeyhliğine vekalet ettiği sanılmaktadır ${ }^{53}$.

Mehmed Emin Efendi'nin vekil şeyh olarak atanması 1910 yllında görevinden azledilen Konya Mevlana Postnişini Abdülhalim Efendi'nin yerine geçen Veled Çelebi ve yine aynı yll Kütahya'dan Kastamonu Mevlevihanesi şeyhliğine atanan Ahmed Remzi Dede arasındaki görüş-

${ }^{49}$ BOA.DH.ID. 84 (17) 5-2 Dahiliye Nezareti'nden Samsun Mutasarnflığ'na (18 Kanun-1 sani 1327).

${ }^{50}$ BOA.DH.ID. 84 (37) 5-13, Dahiliye Nezareti'nden Şura-y1 Devlet Riyaseti'ne (19 Kanun1 sani 1327); 1332. R.4/3, Şura-yı Devlet Komisyon Katipliği (16 Şubat 1327).

${ }^{51}$ BOA.DH.ID.84 (17) 16 Meclis-i idare-i livanın 14 Teşrin-i sani 1329 tarihli karar sureti.

${ }^{52}$ Küçük, a.g.e., s. 253.

${ }^{53}$ Tanrikorur, a.g.e, s. 390 . 
meler sonucunda olmuştur. Ahmed Remzi Dede'den görüş sorulması onun Veled Çelebi ile eski tarihlere dayanan özel hukuku ve şahsiyetinden gelmektedir. Bu görüşmeler sonucunda Ahmed Remzi Dede'nin önerisiyle Mehmed Emin Efendi vekâleten Samsun Mevlevihânesi'ne gönderilmiştir. Assl şeyh olan Yusuf Efendi rüşt çağına gelince onun görevi de sonlanmış olacaktı ${ }^{54}$.

Samsun Mevlevihânesi'nde vekil şeyh olarak kaldığı iki yla yakın zaman zarfinda Hasib Dede, mevlevihâneye sahip çıkabilmek için Zeliha Hanım ile giriştiği uzun ve yıpratıcı mücadeleye rağmen oldukça yararlı hizmetler yapmaya gayret etmiştir. 1912 ylı başlarından itibaren mevlevihâneyi günün şartlarına göre tamir ettirmek ve yenileme mücadelesi kayda değerdir. Onun tarafindan hazırlanan yeni mevlevihâne projesinde minare, minber, selamlık, meydan odası, kahvehane, üç hücreli akarsuyu bulunan bir matbah, firın, kiler, bodrum, gusülhane, abdesthane, iki hela ve su haznesi bulunuyordu ${ }^{55}$. Buna göre tamirat ve yeni kısımların inşası için 131.500 kuruş civarında bir meblağa ihtiyaç duyulmaktayd ${ }^{56}$. Bu para ne Samsun ve ne de başka yerlerden temin edilerek Hasib Dede'nin düşünceleri hayata geçirilemedi. Fakat Samsun Mevlevihanesi geçirdiği badirelere rağmen faal bir konumdaydı. Denizle Anadolu'nun iç kesimlerini birbirine bağlayan hatta Bağdat'a kadar uzanan yolun başlangıç noktası olduğundan yolcuların ve dergâh muhiplerinin sıkça uğradıkları bir yerdi. Eğer bu proje hayata geçirilseydi Osmanlı son döneminde halka hizmet veren devasa bir külliye olarak Samsun'a farklı bir görüntü vereceği muhakkaktı ${ }^{57}$.

Hasib Dede döneminde dergâhın faal bir konuma geldiğini onun döneminde tutulan ve Nejat Göyünç tarafindan yayınlanan masraf listelerinden anlamaktayız. Buna göre bayramlarda, kandil gibi önemli dini gecelerde toplantılar tertip edilerek bunların masrafları dergâhın bütçesinden karşılanırdı. Rumlar tarafindan işletilen dükkânlarda terzilik, kunduracılık, çamaşırcılık, ütücülük, sobacılık ve berberlik gibi meslekler icra edilirdi. Dükkânların 1911-12 yllı geliri olarak 12.693 kuruş gösterilmiştir. Bunun 1524 kuruşu, dükkân ve öşür gelirleri ile

${ }^{54}$ Ahmet Cahit Haksever, "XX. Yüzylla Ü̧ Mevlevi Şeyhi: Veled Çelebi, Abdülbaki Baykara, Ahmet Remzi Akyürek", Tasavvuf, S. 14, Ankara 2005, s. 400.

${ }^{55}$ Tannkorur, a.g.e., s. 390 .

${ }^{56}$ BOA. VGMA. 4641 / 64, Mabeyn-i Hümayun Başkitabeti - Hülasa (19 Mart 1328).

${ }^{57}$ BOA. EV. MKT. 3442 / 67, Mabeyn-i Hümayun Başkitabet Celilesi'ne (5 Nisan 1328). 
Reji idaresinden alınan bahçe kirasıydı. Mevlevihane'ye zaman zaman bağıslar da yapılmaktaydı. Bu listede Samsun mutasarrıfi Mehdi Bey'in verdiği iki lamba ve Aksisada matbaası müdürünün hediye ettiği üç hat levhadan bahsedilmektedir. Samsun'un idari ve sosyal hayatında olan kişilerin buraya ilgi duymaları mevlevihânenin toplum içindeki etkilerini ve yerini göstermesi bakımından önemlidir ${ }^{58}$.

Konya Mevlevi postnişinliği tarafindan Mehmed Emin Efendi'nin vekil şeyh olarak atanmasıyla 1913 ylı sonlarına doğru tekrar mevlevihâne müştemilatının teslimine yönelik hukuki mücadelelerin başladığı görülmektedir ${ }^{59}$.

Yeni vekil şeyh Mehmed Emin Efendi, önceki şeyh gibi mevlevihâneye ait evden Zeliha Hanım'ın çıkarılması için Canik mutasarrıflı̆ı nezdinde mücadeleye başladı. Zeliha Hanım önceden olduğu gibi her defasında mevlevihâne bitişiğinde olan haneyi kendi imkânlarıyla yaptırdığını iddia ediyordu. Fakat Canik mutasarrıflğının ortaya koyduğu hesap dökümlerine göre ve 1906 yllında şeyh Ali Enver Dede ile görülen hesapta yanan mevlevihânenin tamiri dükkânlar, hane ve vakıf gelirleri ile Konya postnişinliğinden alınan borç para ile yapılmıştır. Vakıftan alınan 12 bin kuruş borç, 1907 ylında aşar ve kira gelirinden ödenmişti. Yine vakıf köylerin 1909 ve 1910 yılı öşür gelirlerinden Zeliha Hanım'a olan borçlar kapatılmıştı. Mutasarrıflı̆ın ibraz ettiği kayıtlara göre Zeliha Hanım'ın iddia ettiği gibi Mevlevihane onun kendi imkânlarıyla onarılmamış veya yapılmamışır ${ }^{60}$.

Hasib Dede zamanında tavrını Zeliha Hanım'ın mevlevihâneyi boşaltması yönünde koyan Canik Mutasarrıflığ ve İdare Meclisi, bu seferki gelişmelerde kayıtsız kalmıştır. Mutasarrıflı̆ın kayıtsız kalmasının sebebi, önceki süreçte kınama cezası almalarından kaynaklanmaktadır. Dolayısıyla Zeliha Hanım'in Samsun'da eli ve konumu daha güçlü hale gelmiştir. Konya Mevlana postnişinliği bu nedenle Dâhiliye Nezareti'ne Canik yerel idarecilerini şikayet etmiş, mutasarrıfin "yerli" olması ve idare meclisinin de "istibdad" dönemindeki gibi hareket etmesi sebebiyle

${ }^{58}$ Göyünç, a.g.m., s. $80-81$.

59 BOA.DH.ID.84 (17) 17 Samsun Mevlevihânesi'ne tayin olunan Mehmed Emin Efendinnin yazısına derkenar (21 Teşrin-i sani 1329).

${ }^{60}$ BOA.DH.ID.84 (17) 18 Dilekşeye derkenar (21 Teşrin-i sani 1329). 
mevlevihâne ile ilgili gerekenleri yapmamakla suçlamışur. Çelebi Efendi idare meclisini "hakkaniyetle" ve "şeriat ölgülerine" göre karar vermeye çağırarak, mevlevihâneyi özel mülkü gibi gören Zeliha Hanım'ın oradan çıkarılmasını istemektedir ${ }^{61}$.

Çelebi Efendi, bir taraftan mahkemeye müracaat ederken diğer taraftan da Dâhiliye Nezareti kanalıyla mutasarrıflık üzerinde baskı kurmaya başladı. Canik Mutasarrıflı̆ı kendini mümkün olduğunca meselenin dışına çekmeye çalışarak ortaya çıkan ihtilafin çözüm yerinin mahkemeler olduğu görüşünü vurguluyordu ${ }^{62}$. Eski vekil şeyh döneminde açıkça tavır koyan mutasarrıflık, bu sefer kenarda kalmayı tercih etmekle, Zeliha Hanım'ın elini güçlendirmiş oluyordu. Fakat Çelebi Efendi'nin bu işin üzerine gitmesi üzerine, Şer’i mahkemenin kararına kadar mevlevihâneye ait 8 dükkânın gelirini geçici olarak Evkaf Sandığına devrini kararlaşurdı (Mart 1914). Vakfa ait 2 dükkân ve Zeliha Hanım'ın ikamet ettiği hane ile ilgili bir karar alınmadı. İdare meclisinin 2 dükkân gelirini Zeliha Hanım'a bıraktığı anlaşılmaktadır. Bu konuda vekil Şeyh Mehmed Emin Efendi'ye iddialarını mahkemede ortaya koyması tavsiye dildi ${ }^{63}$.

Bunun üzerine hanenin tahliye edilmesi ve 2 dükkân gelirinin teslimine yönelik sulh mahkemesinde dava açıld ${ }^{64}$. Fakat mahkeme sonucunun beklenmesine karar verilmiştir ${ }^{65}$.

Osmanlı devletinin sonuna kadar Yusuf Efendi'ye vekâleten Mehmed Emin Efendi'nin Mevlevihâne şeyhliğini yürüttüğü sanılmaktadır. Osmanlı döneminde Samsun Mevlevihanesi ile ilgili en son kayttlar Birinci Dünya Savaşı yıllarına rastlamaktadır. Bu yllarda Edirne Mevlevihânesi'nden Kadir Dede'nin listesine göre Samsun Mevlevihânesi şeyhi olarak Mehmed Emin Dede gösterilmekte ve zaviyenin büyüklüğünden bahsedilerek 38 kişiyle Şam'a giden Mevlevi Alayı'na katıldığı belirtilmektedir ${ }^{66}$. vel 1329 ).

${ }^{61}$ BOA.DH.ID. 84 (17) 22, Mevlana Postnişinliği'nden Dahiliye Nezareti’ne (5 Kanun-ı evvel 1329).

${ }^{62}$ BOA.DH.ID.84 (17) 14, Dahiliye Nezareti'nden Canik Mutasarnfluğ'na (11 Kanun-1 ev-

${ }^{63}$ BOA.DH.LD. 84 (17) 19, Canik Mutasarnfluğ'ndan Dahiliye Nezareti'ne (29 Şubat 1329).

${ }^{64}$ BOA.DH.ID. 84 (17) 15, (8 Mart 1330).

${ }^{65}$ BOA.DH.ID. 84 (17) 2, Dahiliye Nezareti'nden Canik Mutasarnfluğ'na (9 Mart 1330).

${ }^{66}$ Tanrikorur, a.g.e., s. 392. 
Samsun Mevlevihanesi, Osmanl devletinin sonuna kadar bu yapı ile varlığını sürdürmüştür. Cumhuriyetin ilanı ile 30 Kasım 1925'te yürürlüğe giren 677 sayılı Tekke ve Zaviyelerin kapatılmasına yönelik çıkan kanuna dayanılarak, Samsun'da eşdeğer dergâhlarla beraber kapatulmıştır.

Samsun Mevlevihane'si Şeyhleri

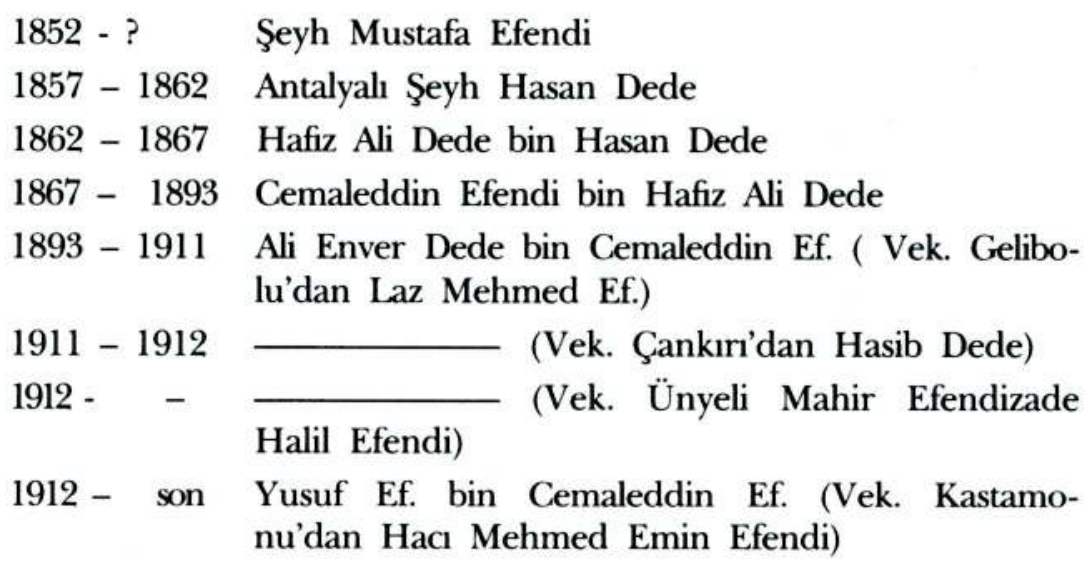

\section{Sonuç}

Samsun'un iktisadi ve siyasi öneminin artmaya başlaması ve Müslüman nüfusun çoğalmasına paralel olarak 14. asırda burada bir mevlevihane kurulduğu mevcut kaynaklara göre tahmin edilmektedir. Bu tarihten sonra mevlevihânenin devem ettiğine yönelik bir bilgi yokken 16. asırda Samsun'da tekrar Mevlevi tekkesinin varlı̆̆ı görülmektedir. Bu asırdan 19. asra kadar Samsun Mevlevihânesi ile ilgili bilgiye şimdiye kadar ulaşlamamışır. 19. asrın yarılarından sonra Samsun'da yeniden kurulan mevlevihane, devletin siyasi ve iktisadi yapısına paralel bir tarzda varliğını sürdürmüştür.

1925 tarihindeki tekke ve zaviyeler ile ilgili düzenlemeye göre kapatıldığı tahmin edilen Samsun Mevlevihânesinin takriben 1940-50 arası bir dönemde yol genişletme çalışmaları esnasında yıkılmıştır. Mevlevihane, modern zamanda halen metruk olan Tekel fabrikası ile II Özel İdaresi arasında bir yerde bulunmaktadır. Ondan geriye sadece yıkıldığı yerden başlayarak Site Camii'nin önünden geçen "Mevlevihane Caddesi" adı kalmışır. 
Mevlevihane'nin, pek bilinmese de Samsun'da 700 ylllık bir geçmişi vardır. İşlevi olduğu dönemlerde kente damgasını vurmuş, idari ve entelektüel çevrelerin gelip gittikleri ve yetiştikleri mekânlardan olmuştur. Onun bu tarihsel geçmişine atfen, eski kurulduğu yerde tekrar bina edilerek bu adla bir kültür mekânı olarak halkın kullanımına sunulması Samsun'a tarihsel bir kimlik kazandıracaktır.

\section{KAYNAKÇA}

\section{Arşiv vesikaları}

BOA. A. MKT. UM. 280 / 87.

BOA. A. MKT. MVL. $146 / 91$.

BOA. EV. MKT. 1683 / 105; 1400 / 13; 3442 / 67,

BOA. DH. MKT. 140 / 32; $2096 / 10$

BOA. MVL. 595 / 50; 674 / 40; 487 / 58.

BEO. 1184 / 88760

BOA. DH.ID. 84 (17)2-2, 1, 2, 3, 3 / 2, 5 / 2-13, 7, 8, 8/3, 9, 10/2-4, $12,14,15,16,17,18,19,22$.

BOA. VGMA. $4641 / 64$,

VGMA ( Vakılar Genel Müdürlüğü Arşivi) Defter no: 304.

Ikdam, 9 Mayıs 1317, sayı: 2481.

\section{Kitap ve Makaleler}

Darkot, Besim, "Samsun”, Islam Ansiklobedisi (IA), 10, İstanbul 1988.

Haksever, Ahmet Cahit, "XX. Yüzylda Üç Mevlevi Şeyhi: Veled Çelebi, Abdülbaki Baykara, Ahmet Remzi Akyürek”, Tasavvuf, S. 14, Ankara 2005. s. 383 - 415.

Horata, Osman, "Mevlana ve Divan Şairleri", Hacettepe Úniversitesi Edebiyat Fakïltesi Dergisi, 1999 Özel sayısı. Ankara 1999. s. 43 - 56.

Gölpınarlı, Abdülbaki, Mevlanadan Sonra Mevlevilik, İstanbul 1953.

Göyünç, Nejat, "Das Mevlevihane in Samsun", The foumal Ottoman Studies, XIV, (Istanbul 1994). S. $77-90$.

Küçük, Hülya, "Sultan Veled'in İbtida Name'sine Göre Mevlevi Halifeleri", http://www.mevlana.selcuk.edu.tr/belge/sumam-bildir-III/bildiri-IIIpdf/B10\%20Hulya\%20Kucuk.pdf. 
Küçük, Sezai, Mevleviliğin Son Yüzyll, İstanbul 2007.

, "Örnek Bir Mevlevi: Üsküdar Mevlevihanesi Son Postnişini Ahmed Remzi Dede (Akyürek)”, Úsküdar Sempozyumu IV, (3-5 Kasim 2006).

Şafak, Yakup, "XIX.- XX. Yüzylllarda Samsun Mevlevihanesi”, Gę̧mişten Geleceğe Samsun II, Edit: Cevdet Yılmaz. Samsun 2008. s. 463 471.

Tanrıkorur, Barihuda Ş., Türkiye Mevlevihanelerinin İ Yüzü II, (Selçuk Üniversitesi Sosyal Bilimler Enstitüsü Yayınlanmamış Doktora Tezi), (Konya 2000),

Ocak, Ahmet Yaşar, "Türkiye Tarihinde Merkezi İktidar ve Mevleviler (XIII-XVIII. Yüzyllar) Meselesine Kısa Bir Bakış", Türkiyat Araştrrmalan Dergisi, S. 2, (Mays 1996). s. 17 - 22. 
